\section{Growing Saffron Crocus in the Northeastern United States: Effects of Winter Protection and Planting Density}

\author{
Rahmatallah Gheshm ${ }^{1}$ and Rebecca Nelson Brown ${ }^{1}$
}

AdDitional INDEX wORDs. corm density, Crocus sativus, herbs, low tunnels, New England, Rhode Island, spices

\begin{abstract}
Summary. Saffron is well known as the most expensive spice in the world by weight. It is the dried stigmas of the saffron crocus (Crocus sativus). Besides being well known as a culinary spice, saffron is also important in the pharmaceutical, cosmetic, and dye industries. Saffron crocus is cultivated in a wide range of environments, from the Mediterranean to the Middle East, and even to northern India's subtropical climate. Saffron crocus is an environmentally friendly and low-input crop, making it a perfect match for lowinput and organic farming, and sustainable agricultural systems. The objective of this study was to evaluate the possibility of producing saffron in New England. The study was conducted from Sept. 2017 to Dec. 2019 at the University of Rhode Island. Two different corm planting densities and two winter protection methods were evaluated. In 2018 , corm planting density did not affect the number of flowers per unit area or total stigma yields, but flowers from the lowdensity plots produced significantly $(P<0.05)$ heavier pistils than flowers from the high-density plots. In 2019, planting density had no effect on flower number, stigma yield, or pistil dry weight. In 2018, flower number, stigma yield, and pistil dry weight were similar to subplots that had been covered with low tunnels the previous winter and subplots that had not been covered. However, in 2019, the plants in the subplots that remained exposed during the winter produced significantly more $(P<0.05)$ flowers than the plants in the subplots that were in low tunnels for the winter. Saffron yields followed the same pattern, with the unprotected subplots yielding $57 \%$ more than the protected subplots $(P<0.05)$. These data indicate that winter protection is not beneficial for saffron crocus production in Rhode Island. The use of winter protection increases production costs and can decrease yields.
\end{abstract}

$S$ affron, the dried stigmas of saffron crocus (Crocus satious) flowers, is the most expensive spice by weight and is known as "red gold." It is a well-known and ancient culinary spice, and it is used in cosmetics and perfumes, and as a textile dye (Gohari et al., 2013; Mzabri et al., 2019). Like many herbs, saffron contains phytochemicals with important medicinal

Received for publication 3 Mar. 2021. Accepted for publication 15 June. 2021.

Published online 22 July 2021.

${ }^{1}$ Department of Plant Sciences and Entomology, University of Rhode Island, Kingston, RI 02881

We acknowledge the Rhode Island Agricultural Experiment Station for their support and thank Timothy Sherman for his help with fieldwork.

R.G. is a postdoctoral fellow at the University of Rhode Island.

R.N.B. is the corresponding author. E-mail: brownreb@uri.edu.

This is an open access article distributed under the CC BY-NC-ND license (https://creativecommons. org/licenses/by-nc-nd/4.0/).

https://doi.org/10.21273/HORTTECH04836-21 properties that are currently being evaluated as treatments for anxiety, cancer, Parkinson's disease, Alzheimer's disease, glaucoma, and macular degeneration (Christodoulou et al., 2015). In southern Europe, northern Africa, and western Asia, saffron is used to flavor everything from ice cream, yogurt, candy, and liquor to baked goods, curries, rice, pasta, meat, and seafood. It is not a traditional flavoring in North America, but saffron consumption is growing with changing demographics and an increased demand for natural flavoring and coloring agents, and nutraceutical foods (Grand View Research, 2020). The northeastern United States has been home to large immigrant populations since the 18th century. Since 1970, the immigrant population has increasingly come from saffron-consuming regions, including western Asia, India, Southeast Asia, Portugal, and Brazil (Marcuss and Borgos, 2004). Most saffron consumed in the United States is imported. In 2019, the United States. imported 77,365 kg of saffron, valued at $\$ 15.7$ million (United Nations, 2021). Imports have increased by more than $500 \%$ since 2009 .

Saffron crocus is an annual herbaceous plant that reproduces vegetatively via corms and is usually cultivated as a perennial (Fallahi and Mahmoodi, 2018; Koocheki and Seyyedi, 2020). Each corm can produce one to four fragrant purple flowers, which emerge from inside cataphylls in the early fall. The grass-like leaves emerge together with or after the flowers, and persist through winter and spring (Fig. 1). Each flower has three golden-yellow stamens and one red pistil. This pistil is made up of three stigmas that, when dried, become the saffron spice (Dar et al., 2017). Saffron crocus is completely sterile (triploid form, $x=8$; $2 n=3 x=24)$ and does not set viable seeds (Gresta et al., 2008). Therefore, the crop must be propagated by small corm (cormlet) multiplication. Corms are formed during vegetative growth in the spring, and flower buds are initiated before the onset of summer dormancy (Begoña et al., 2021).

Saffron crocus is sensitive to photoperiod and can only grow between latitudes $30^{\circ}$ and $50^{\circ}$ (Golmohammadi, 2014). In Iran, saffron crocus is grown

\begin{tabular}{llll}
\hline $\begin{array}{l}\text { Units } \\
\begin{array}{l}\text { To convert U.S. to SI, } \\
\text { multiply by }\end{array}\end{array}$ & U.S. unit & SI unit & $\begin{array}{l}\text { To convert SI to U.S., } \\
\text { multiply by }\end{array}$ \\
\hline 0.4047 & $\mathrm{acre}(\mathrm{s})$ & $\mathrm{ha}$ & 2.4711 \\
0.3048 & $\mathrm{ft}$ & $\mathrm{m}$ & 3.2808 \\
0.0929 & $\mathrm{ft}^{2}$ & $\mathrm{~m}^{2}$ & 10.7639 \\
2.54 & inch $(\mathrm{es})$ & $\mathrm{cm}$ & 0.3937 \\
25.4 & inch $(\mathrm{es})$ & $\mathrm{mm}$ & 0.0394 \\
0.4536 & $\mathrm{lb}$ & $\mathrm{kg}$ & 2.2046 \\
1.1209 & $\mathrm{lb} / \mathrm{acre}$ & $\mathrm{kg} \cdot \mathrm{ha}^{-1}$ & 0.8922 \\
0.0254 & $\mathrm{mil}(\mathrm{s})$ & $\mathrm{mm}$ & 39.3701 \\
28.3495 & $\mathrm{Oz}$ & $\mathrm{g}$ & 0.0353 \\
305.1517 & $\mathrm{Oz} / \mathrm{ft}^{2}$ & $\mathrm{~g} \cdot \mathrm{m}^{-2}$ & 0.0033 \\
$\left({ }^{\circ} \mathrm{F}-32\right) \div 1.8$ & ${ }^{\circ} \mathrm{F}$ & ${ }^{\circ} \mathrm{C}$ & $\left({ }^{\circ} \mathrm{C} \times 1.8\right)+32$ \\
& & &
\end{tabular}






Fig. 1. The production cycle of saffron crocus. Saffron production starts with planting dormant mother corms during the summer (June to September). Mother corms produce flowers in October and November; these flowers are harvested to produce saffron. Foliage emerges during or just after flowering, and vegetative growth continues through late spring. Mother corms die after forming the secondary corms in late spring. Secondary corms form flower buds in early summer and are dormant from June to September.

as an irrigated crop under arid conditions. However, saffron crocus is also grown in Kashmir, where annual precipitation averages 1000 to $1500 \mathrm{~mm}$ (Golmohammadi, 2014; Gresta et al., 2008). Saffron crocus is not commonly grown in mesic temperate regions today, but centers of saffron production have existed in southeastern Pennsylvania, the Cornwall region of the United Kingdom, and central Europe in the past (Alonso et al., 2012, Heinitsh, 1867). The crop can tolerate an air temperature range from -22 to $40^{\circ} \mathrm{C}$ (Rezvani-Moghaddam, 2020). Saffron crocus requires medium-texture soil with functional drainage capacity, and it is tolerant of the high salinity in the soil in dry areas (Kafi, 2006). Gresta et al. (2008) reported that the optimum $\mathrm{pH}$ is in the range of 6.8 to 7.8 (from neutral to slightly alkaline), but Simon et al. (1984) reported that saffron crocus will grow in soil with a $\mathrm{pH}$ of 5.8 to 7.8. Saffron crocus is often grown in arid, infertile soils, but fertile soil is the basis for good saffron production
(Gresta et al., 2008), and boosting the soil's organic matter is one of the most substantial factors for maximizing saffron yield (Yarami and Sepaskhah, 2015).

Saffron crocus is an important cash crop for agricultural smallholders living off marginal areas in Iran, North Africa, Kashmir, and Mediterranean countries (Schmidt et al., 2019). Currently, most saffron crocus is grown in the traditional production region stretching from Spain and the western Mediterranean east to Kashmir. More than $90 \%$ of the global saffron supply is grown in Iran (Food and Agriculture Organization of the United Nations, 2018).

Saffron is the most expensive spice for customers and is usually sold by the gram, which equals 200 to 300 filaments. The price for saffron in the North American retail market is highly variable. Low-quality imported saffron is available for $\$ 10$ per $\mathrm{g}$, whereas the organic saffron produced in California sells for $\$ 56$ per g (M. Skinner, personal communication). Saffron traded through global commodity markets is of questionable quality resulting from widespread problems with adulteration, poor packaging, and difficulty tracking bulk exports (Mohammadi and Reed, 2020). Consumers are willing to pay a premium for high-quality saffron, which can be source-verified. Saffron yields range widely, from 2 to $28 \mathrm{~kg} \cdot \mathrm{ha}^{-1}$, depending on the climate, field age, and farming practices used (Cardone et al., 2020). Yields are higher in mesic climates with fertile soils. Saffron crocus is recommended as a crop for small-scale farming because it has a high value per hectare and requires few agronomic inputs (Cardone et al., 2020). Traditional saffron crocus production relies on hand labor for most operations. Studies in Iran have shown that 1 ha of saffron crocus requires 270 person-days of labor per year for all the production practicesfrom sowing through drying of the stigmas (Kafi, 2006). In Europe, labor requirements are much less because most aspects of saffron crocus production have been mechanized, with the 
exception of harvest (Alonso DiazMarta et al., 2006).

Most saffron crocus is still harvested by hand, pinching each flower from the plant at the stem base. (Gresta et al., 2008). Stigmas are then separated from anthers and tepals by hand, and are air-dried at $35^{\circ} \mathrm{C}$. Flowers must be harvested as soon as they appear, and stigmas must be separated before the flowers wilt (Molafilabi, 2006). The lack of mechanization for saffron crocus harvest is a result of the delicacy of flowers and stigmas, lack of uniformity of flower emergence, and the need to keep soil from contaminating stigmas (Alonso Diaz-Marta et al., 2006; Gresta et al., 2008). The timing of flowering in saffron crocus is controlled by soil moisture and temperature; harvest typically lasts 15 to $25 \mathrm{~d}$ (Molafilabi, 2004). The short harvest window and lack of mechanization reduce economies of scale, benefiting small-scale producers.

The optimal corm density depends on the climate and how long the field will remain in production before the corms are dug and replanted. In Iran, saffron crocus is traditionally planted at a density of 50 corms $/ \mathrm{m}^{2}$, and fields are dug every 5 to 8 years because digging and replanting corms is labor intensive. However, researchers have found that using a density of 100 corms $/ \mathrm{m}^{2}$ and digging corms every 2 years improves yields (Koocheki et al., 2019). In Italy, Greece, and Spain, corms are dug every year, with planting densities of 200 to 230 corms $/ \mathrm{m}^{2}$ (Molafilabi, 2006). Annual or biennial cropping of saffron crocus simplifies weed management but increases soil disturbance.

In the northeastern United States, extremely high land values have resulted in most farms being land limited, and agricultural production is dominated by high-value specialty crops and livestock [U.S. Department of Agriculture (USDA), 2019]. Saffron crocus has the potential to be a good fit for agriculture in the region. In addition to extremely high value per unit area, saffron crocus requires minimal labor inputs outside of the harvest period, making it attractive to farmers who are employed off-farm. The harvest period for saffron crocus is after the primary harvest period for most other specialty crops in the northeastern United States, so it could provide extended employment for seasonal workers. Saffron crocus has few insect and disease problems, and is not a heavy feeder, so it is a good candidate for organic production. Unlike most specialty crops, saffron has a long shelf life once dried and is easy to ship. Saffron can be an important part of the diversified local market farm in the northeastern United States today, as it was in eastern Pennsylvania during the 18th and 19th centuries (Heinitsh, 1867).

Historically, saffron production in the northeastern United States was concentrated in southeastern Pennsylvania (USDA zone 7). Ghalehgolabbehbahnai et al. (2017) showed that saffron crocus could be cultivated with acceptable results in high tunnels in Vermont (USDA zone 4), but little is known about the best practices for field production of saffron crocus in New England. The objectives of this study were to evaluate saffron crocus as a new specialty crop for New England, to determine whether winter protection was beneficial for saffron crocus production in Rhode Island (USDA zone 6a), and to evaluate corm planting densities for a mesic, high-fertility environment assuming a planting life of 3 years.

\section{Materials and methods}

Field preparation. The experiment was conducted from Sept. 2017 to Dec. 2019 at the University of Rhode Island's Gardiner Crops Research Center in Kingston, RI. The field soil was sandy loam, with a $\mathrm{pH}$ of 5.9 and $3.6 \%$ organic matter. The experimental field was plowed on 13 Sept. 2017, and before disking and leveling fertilizers were broadcast and incorporated into the soil to provide $110 \mathrm{lb} /$ acre nitrogen $(\mathrm{N}), 17 \mathrm{lb} /$ acre phosphorus (P), and $50 \mathrm{lb} /$ acre potassium $(\mathrm{K})$. Nitrogen application was based on standard practices for saffron crocus production in Iran; other nutrient amendments were based on soil test results.

Planting. Planting took place 14 to 18 Sept. Saffron crocus corms weighing 9 to $10 \mathrm{~g} / \mathrm{corm}$ were obtained from Roco Saffron (Voorhout, Netherlands). Corms were planted at a depth of $15 \mathrm{~cm}$ in level beds $4 \mathrm{~m}$ long and $0.75 \mathrm{~m}$ wide. Beds were separated by an unplanted area $0.5 \mathrm{~m}$ wide. Two planting densities were used. Plots planted to the higher density of 162 corms $/ \mathrm{m}^{2}$ had nine rows of saffron crocus corms with $8 \mathrm{~cm}$ between rows and $7.5 \mathrm{~cm}$ between plants in the row. Lower density plots with 120 corms / $\mathrm{m}^{2}$ had nine rows spaced at $12 \mathrm{~cm}$ between rows and $6.5 \mathrm{~cm}$ between plants in the row. Densities were selected based on results of previous research in Iran and Europe. The density of 120 corms $/ \mathrm{m}^{2}$ was selected by adjusting the Iranian density (Koocheki et al., 2019) to account for higher soil fertility in Rhode Island, whereas the density of 162 corms $/ \mathrm{m}^{2}$ was selected by adjusting the European density for short-duration perennial cropping (Molafilabi, 2006).

Maintenance. Rhode Island has a mesic climate with an annual precipitation of $1200 \mathrm{~mm}$, so no irrigation was required. In 2018 and 2019, fertilizers were broadcast and raked into the soil in the first week of October to provide $50 \mathrm{lb} /$ acre $\mathrm{N}, 9.2 \mathrm{lb} /$ acre $\mathrm{P}$, and $25.3 \mathrm{lb} /$ acre K. Saffron crocus was side-dressed with urea $(46 \mathrm{~N}-0 \mathrm{P}-0 \mathrm{~K})$ in mid-March and mid-April of each year to provide $30 \mathrm{lb} /$ acre $\mathrm{N}$ at each application. Before flowering in Fall 2017, annual weeds were controlled by cultivating with a double wheel hoe (Hoss Tools, Norman Park, GA) and a hand rake on 2 Oct. 2017. After flowering, all planted areas and alleys were surface-mulched with a $5-\mathrm{cm}$ layer of locally sourced shredded deciduous tree leaves to suppress annual winter weed growth. Weeds emerging through the saffron crocus canopy were hand-pulled on 1 and 22 May of each year. At our location, saffron crocus was dormant from mid-June through September. During the dormant period in 2018, weeds were controlled by monthly cultivating with a walk-behind rototiller (Troy Bilt, Valley City, OH) to a maximum depth of $8 \mathrm{~cm}$. The study area was originally planted with four replications, but meadow voles (Microtus pennsylvanicus) damaged corms in some plots during Winter 2017-18. The damaged plots were removed from the study, leaving three replications. In Sept. 2018 , the experimental field was protected against meadow voles by galvanized steel hardware cloth with a 0.5 inch mesh laid directly on the soil surface (Fig. 2). The mesh was large enough for saffron crocus to grow through but small enough to keep meadow voles from burrowing and 


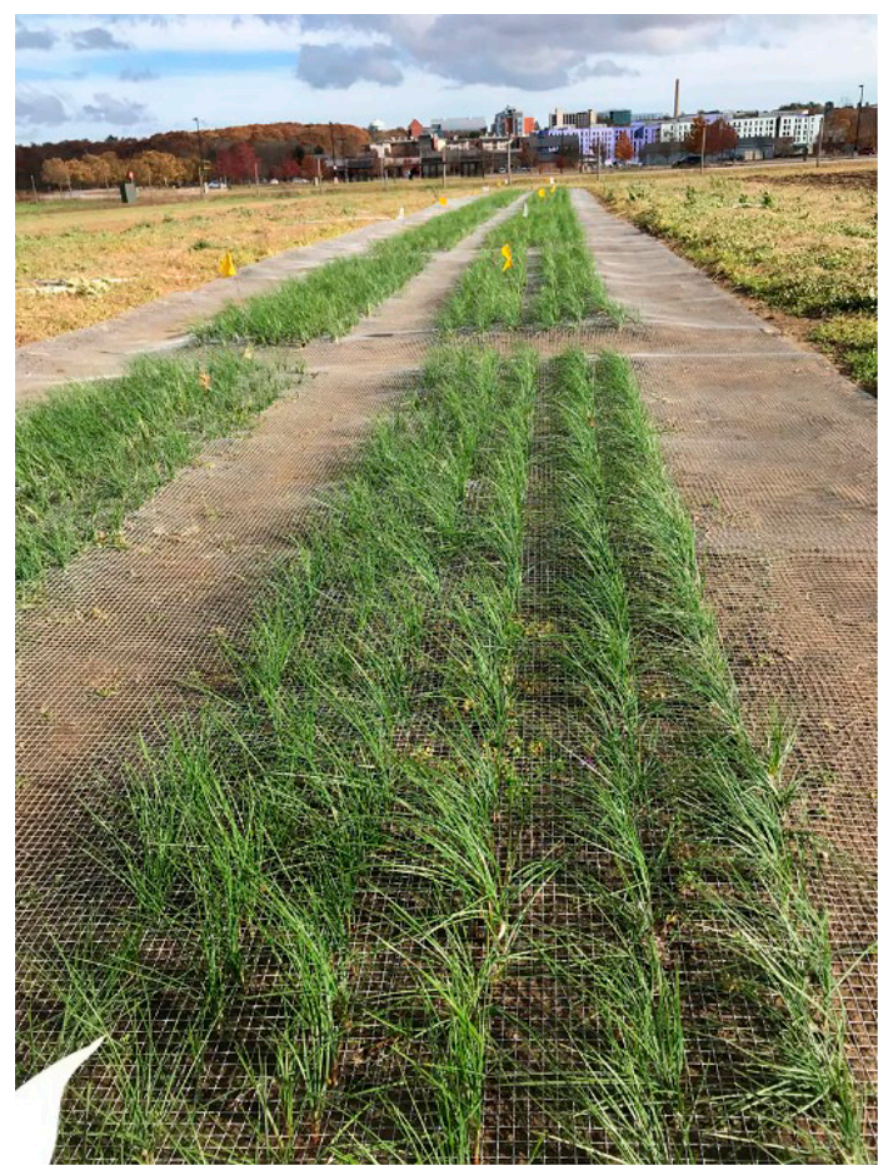

Fig. 2. The experimental field was protected against meadow voles by galvanized steel hardware cloth with 0.5 -inch $(1.27-\mathrm{cm})$ mesh laid on the soil surface. The mesh was big enough for saffron crocus to grow through and small enough to keep voles from feeding on corms. The photo was taken 3 Nov. 2018.

eating corms. In 2019, the weeds were controlled using a flame weeder (Weed Dragon; Flame Engineering, LaCrosse, KS) on 8 Aug. and 10 Sept. On 12 Sept., the hardware cloth was removed, and rhizomatous weeds were controlled by physical removal. The experimental field was top-dressed with a 1 -inch layer of field soil to ensure sufficient coverage of daughter corms, which form on top of the mother corm each year. The hardware cloth was replaced after top-dressing.

SAFFron CROCUS HARVEST. Flowering time in 2017 began on 23 Oct. and ended on 7 Nov. In both 2018 and 2019, flowering began on 15 Oct. and finished on 7 and 5 Nov., respectively. Blossoms were picked by hand every morning. After harvest, flowers were kept refrigerated at $4{ }^{\circ} \mathrm{C}$ until processing. Stigmas were separated from anthers and tepals and oven-dried (Thelco model 18; GCA/ Precision Scientific, Chicago, IL) at $35^{\circ} \mathrm{C}$ for $12 \mathrm{~h}$ and weighed on an enclosed balance. cus production areas are warmer than winter temperatures in southern New England, and saffron crocus foliage grows actively all winter. Low tunnels in protected subplots were installed 10 $\mathrm{d}$ after the last harvest and were removed by the end of March each year (Fig. 3). The low tunnel design was based on that developed by Sideman et al. (2012) for vegetables. Low tunnels were $80 \mathrm{~cm}$ high, $90 \mathrm{~cm}$ wide, and $4 \mathrm{~m}$ long. They consisted of $1 / 2$ inch-diameter polyvinylchloride pipe hoops spaced every $0.65 \mathrm{~m}$, and were covered with a spun-bonded polypropylene fabric layer (Agribon-19; Berry Plastics, Evansville, IN) and a layer of clear 6-mil polyethylene greenhouse plastic (Tufflite IV, Berry Plastics). Covers were held in place with steel reinforcing bars and sandbags.

EXPERIMENTAL DESIGN AND DATA ANALYSIs. The study used a split-plot design with corm density as the main plot effect and winter protection as the subplot effect. Treatments were replicated three times. The main plots were $8.5 \mathrm{~m}$ long and included two 4-m beds; each subplot was a single bed $4 \mathrm{~m}$ long and $0.75 \mathrm{~m}$ wide (Fig. 4). Subplots within each main plot were separated by a $0.5-\mathrm{m}$ unplanted buffer to accommodate the low tunnels during the winter. Adjacent main plots were separated by an unplanted buffer $1 \mathrm{~m}$ long. Data were collected on the number of flowers per subplot, the weight of dried pistils per subplot, and the single stigma dry

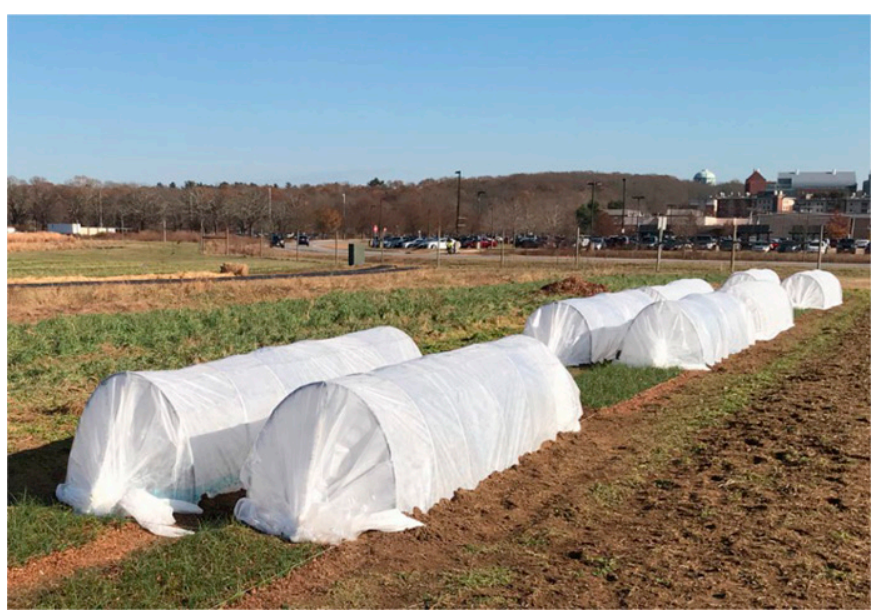

Fig. 3. Low tunnels in protected saffron crocus subplots were installed $10 \mathrm{~d}$ after the last harvest and were removed by the end of March each year. Low tunnels used as winter protection were $80 \mathrm{~cm}(2.62 \mathrm{ft})$ high, $90 \mathrm{~cm}(2.95 \mathrm{ft})$ wide, and 4 $\mathrm{m}(13.12 \mathrm{ft})$ long. They consisted of 0.5 -inch-diameter $(1.27-\mathrm{cm}$-diameter) polyvinylchloride pipe hoops spaced every $0.65 \mathrm{~m}(2.13 \mathrm{ft})$, and were covered with a layer of spun-bonded polypropylene fabric and a layer of clear 6-mil (0.15$\mathrm{mm})$ polyethylene greenhouse plastic. The photo was taken 16 Nov. 2017. 


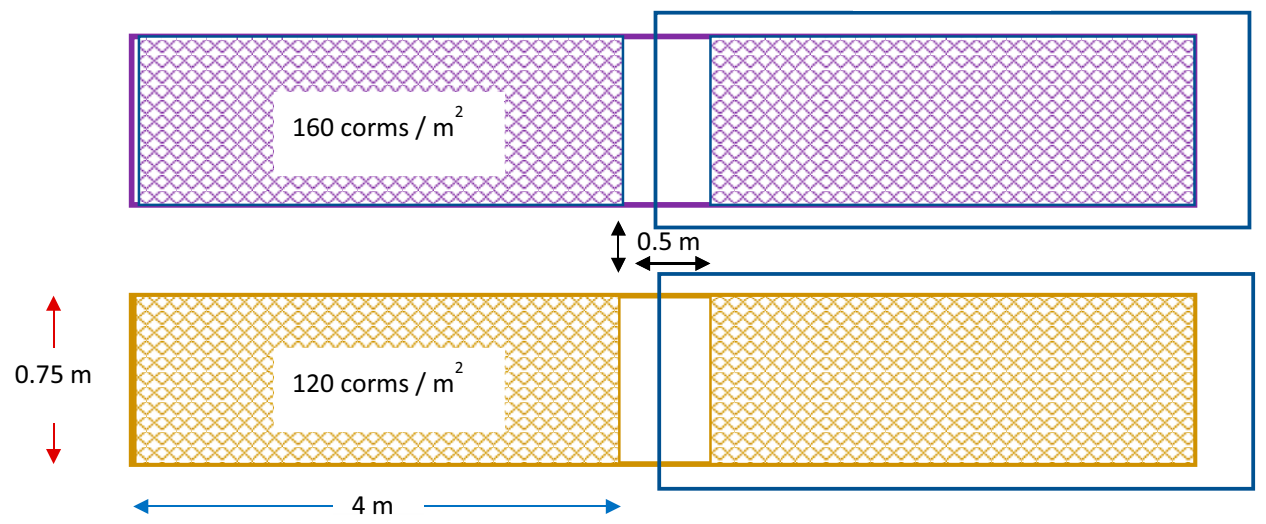

Fig. 4. Diagram of one block of the experimental saffron crocus field showing the arrangement of the plots. Corms were planted at a depth of $15 \mathrm{~cm}$ (5.9 inches) in level beds. Each main plot for assessing effects of corm planting density contained two subplots. Subplots were used to test the effects of winter protection by low tunnels. $1 \mathrm{~m}=3.2808 \mathrm{ft}, 1 \mathrm{corm} / \mathrm{m}^{2}=$ $0.0929 \mathrm{corm} / \mathrm{ft}^{2}$.

weight. Years were analyzed separately, as is standard practice in saffron crocus production studies (Khademi et al., 2014). Data were not analyzed for the effects of winter protection on the 2017 harvest. Data were analyzed using PROC MIXED with the pairwise comparison of least mean squares (SAS version 9.4; SAS Institute, Cary, NC)

\section{Results and discussion}

EFFECTS OF CORM PLANTING DENSITY. Interactions between corm planting density and winter protection were not significant in either year for any of the dependent variables. In 2017 , plots planted at a higher corm density yielded significantly more flowers and dry saffron than plots planted at a lower corm density. This was expected, because in the establishment year, all corms are of similar size with a similar number of flower buds. Corm planting density did not affect either flower number or dry saffron yield significantly in 2018 and 2019 (Table 1). In 2018, flowers in the low-density plots had significantly $(P=0.01)$ heavier pistils than flowers in the highdensity plots. In 2019, pistil weight was numerically greater in the lowdensity plots than in the high-density plots, but the difference was not significant $(P=0.14)$ (Table 1$)$. Gresta et al. (2009) similarly reported that increases in the number of flowers per unit area were associated with decreases in pistil weight. The lack of significant differences in dry saffron yield suggests there is no advantage to using the higher planting density, particularly because increasing corm planting density increases the cost of establishing a saffron crocus production field.

Saffron crocus is a self-propagating annual, with new corms being produced each year. Each plant produces multiple daughter corms, resulting in an exponential increase in population at low planting densities. However, as a result of competition, as corm density increases, the number of daughter corms per plant and the number of flowers per corm decrease (Elhajj et al., 2019). In perennial production systems, flower numbers and saffron yields increase for several years and then decrease as plants become overcrowded. In our study, both flower number and dry saffron yield increased significantly $(P<0.05)$ from 2017 (establishment year) to 2018, but did not differ between 2018 and 2019 (data not shown).

Table 1. The effect of saffron crocus corm density on flower number and yield of dry stigmas in the field in 2018 and 2019 in Kingston, RI. The high-density treatment had $160 \mathrm{corms} / \mathrm{m}^{2}$ and the low-density treatment had 120 corms/ $\mathrm{m}^{2}$.

\begin{tabular}{llccc}
\hline Yr & $\begin{array}{c}\text { Planting } \\
\text { density }\end{array}$ & $\begin{array}{c}\text { Flowers } \\
\left(\mathbf{n o .} / \mathbf{m}^{\mathbf{2}}\right)^{\mathbf{z}}\end{array}$ & $\begin{array}{c}\text { Dry saffron } \\
\text { yield }\left(\mathbf{g} \cdot \mathbf{m}^{-2}\right)^{\mathbf{z}}\end{array}$ & $\begin{array}{c}\text { Single pistil } \\
\text { dry wt }(\mathbf{g})^{\mathbf{z}}\end{array}$ \\
\hline 2017 & High & 26 & 0.14 & 0.0056 \\
& Low & 20 & $0.1 \mathrm{l}$ & 0.0053 \\
2018 & High & $261 \mathrm{a}^{\mathrm{y}}$ & $1.35 \mathrm{a}$ & $0.0051 \mathrm{~b}$ \\
& Low & $220 \mathrm{a}$ & $1.24 \mathrm{a}$ & $0.0056 \mathrm{a}$ \\
& High & $179 \mathrm{a}$ & $0.93 \mathrm{a}$ & $0.0051 \mathrm{a}$ \\
& Low & $208 \mathrm{a}$ & $1.15 \mathrm{a}$ & $0.0055 \mathrm{a}$ \\
\hline
\end{tabular}

${ }^{\mathrm{z}} \mathrm{l}$ corm or flower $/ \mathrm{m}^{2}=0.0929$ corm or flower $/ \mathrm{ft}^{2}, \mathrm{l} \mathrm{g} \cdot \mathrm{m}^{-2}=0.0033 \mathrm{oz} / \mathrm{ft}^{2}, \mathrm{l} \mathrm{g}=0.0353 \mathrm{oz}$.

${ }^{\mathrm{y}}$ Within each year, differences among means labeled by the same letter are not significant at $P=0.05$.

Table 2. The effect of winter protection on flower number and dry stigma weight of saffron crocus in Kingston, RI. Low tunnels used as winter protection consisted of $1 / 2$-inch-diameter $(1.27-\mathrm{cm})$ polyvinylchloride pipe hoops spaced every $0.65 \mathrm{~m}(2.13 \mathrm{ft})$, and were covered with a layer of spun-bonded polypropylene fabric and a layer of clear $6-\mathrm{mil}(0.15-\mathrm{mm})$ polyethylene greenhouse plastic.

\begin{tabular}{llccc}
\hline Yr & $\begin{array}{c}\text { Winter } \\
\text { protection }\end{array}$ & $\begin{array}{c}\text { Flowers } \\
\left(\text { no. } / \mathbf{m}^{2}\right)^{\mathrm{z}}\end{array}$ & $\begin{array}{c}\text { Dry saffron } \\
\text { yield }\left(\mathbf{g} \cdot \mathbf{m}^{-2}\right)^{\mathrm{z}}\end{array}$ & $\begin{array}{c}\text { Single pistil } \\
\text { dry wt }(\mathbf{g})^{\mathrm{z}}\end{array}$ \\
\hline 2018 & Protected & $272 \mathrm{a}^{\mathrm{y}}$ & $1.50 \mathrm{a}$ & $0.0055 \mathrm{a}$ \\
& Unprotected & $210 \mathrm{a}$ & $1.09 \mathrm{a}$ & $0.0052 \mathrm{~b}$ \\
2019 & Protected & $150 \mathrm{~b}$ & $0.80 \mathrm{~b}$ & $0.0053 \mathrm{a}$ \\
& Unprotected & $238 \mathrm{a}$ & $1.27 \mathrm{a}$ & $0.0054 \mathrm{a}$ \\
\hline
\end{tabular}

${ }^{\mathrm{z}} \mathrm{l}$ flower $/ \mathrm{m}^{2}=0.0929$ flower $/ \mathrm{ft}^{2}, \mathrm{l} \mathrm{g} \cdot \mathrm{m}^{-2}=0.0033 \mathrm{oz} / \mathrm{ft}^{2}, \mathrm{l} \mathrm{g}=0.0353 \mathrm{oz}$.

${ }^{y}$ Within each year, differences among means labeled by the same letter are not significant at $P=0.05$. 


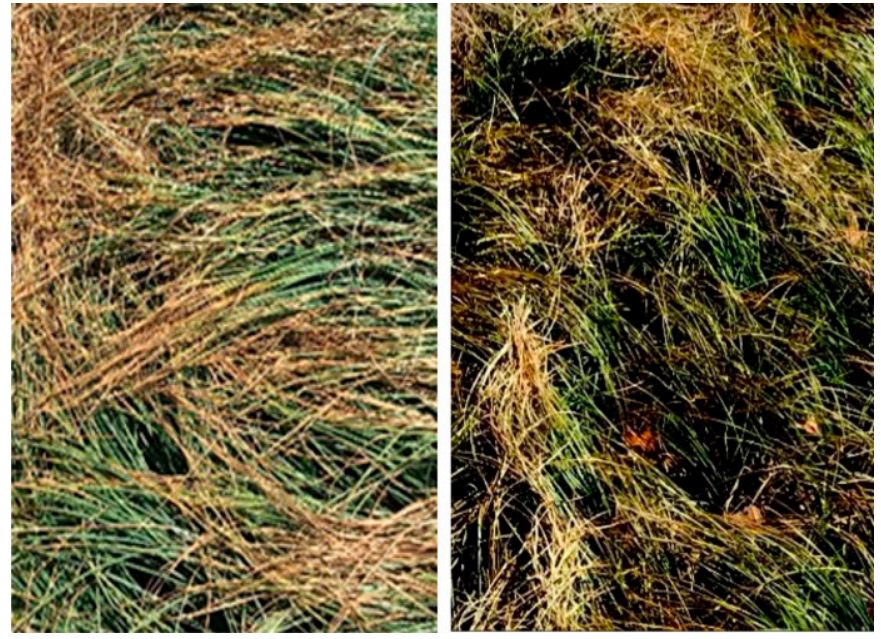

Fig. 5. Saffron crocus plants that were protected by low tunnels over the winter had larger leaves and more total foliage than plants that were unprotected over the winter. (Left) Foliage in the protected subplots and (right) foliage in the unprotected subplots. The photo was taken 2 Apr. 2019.

These results, combined with the lack of significant effects of corm planting density in 2018 and 2019, suggest that by 2019 , corm density was similar in both treatments, and corms were beginning to suffer from overcrowding. Andabjadid et al. (2015) and Temperini et al. (2009) found that higher planting densities increased yields initially but that corms became overcrowded more quickly.

EFFECTS OF WINTER PROTECTION. In 2018, winter protection did not affect flower number or dry saffron yield significantly. However, the plants that were protected by low tunnels over the winter produced significantly $(P=0.03)$ heavier pistils than plants that were unprotected over the winter (Table 2). In 2019, the plants that remained exposed the previous winter produced significantly $(P=0.02)$ more flowers than the plants that were protected during the winter. Saffron yields followed the same pattern, with the unprotected subplots yielding $\mathbf{5 7 \%}$ more than the protected subplots (Table 2). Pistil dry weight was unaffected by winter protection in 2019 .

Saffron yields and flower number increased by $17 \%$ and $13 \%$, respectively, from 2018 to 2019 for subplots that were not protected during the winters. In subplots that received winter protection, saffron yields and flower numbers were $47 \%$ and $45 \%$ lower, respectively, in 2019 than in 2018. The patterns of change were significantly different at $P=0.03$ for saffron yield and $P=0.05$ for flower number. Pistil weight did not differ across years for either winter protection treatment.

In both years, we observed that the plants that were protected by low tunnels during the winter had larger leaves and more total foliage than photo was taken 24 Apr. 2019. plants that were unprotected during the winter (Fig. 5). However, the foliage senesced $10 \mathrm{~d}$ earlier in the protected subplots than in the unprotected subplots (Fig. 6). Gresta et al. (2008) and Molina et al. (2005) reported that temperature is one of the environmental factors that controls growth and flowering in crocus (Crocus sp.). Also, Rahimi et al. (2017) suggested that corm development depends directly on the condition of shoots and leaves. The leaves' photosynthetic activity in the vegetative phase during the winter and early spring months contributes to the formation of daughter corms (RenauMorata et al., 2012). Early senescence may have resulted in smaller daughter corms. Small corms $(<6 \mathrm{~g})$ usually do not flower in the first year and also exert a negative effect on flowering in subsequent years when saffron crocus is managed as a perennial crop (Andabjadid et al., 2015; de Juan et al., 2009; Gresta et al., 2008). The decrease in yields and flower number over time observed in the protected subplots in our study is consistent with the effects of large numbers of small corms. Molina et al.

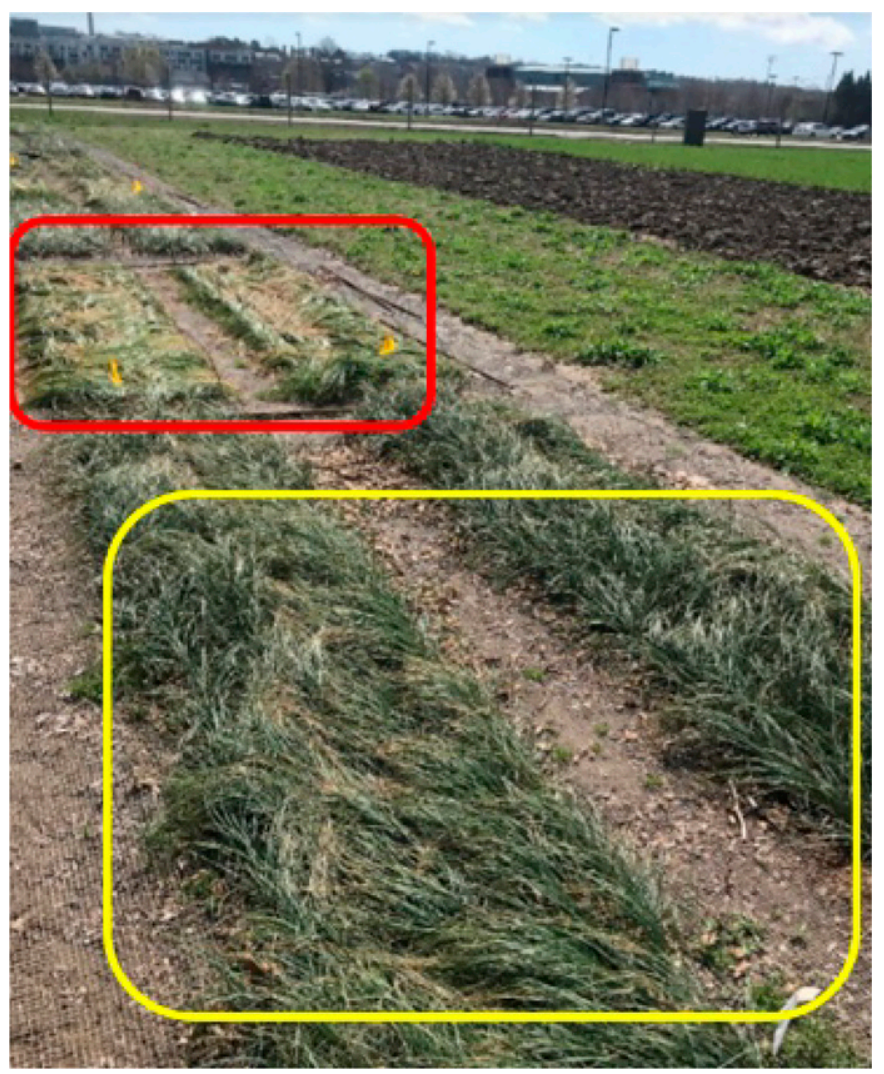

Fig. 6. In 2018 and 2019, saffron crocus leaves in the subplots that were protected by low tunnels over the winter senesced $10 \mathrm{~d}$ earlier (inside the red rectangle) than in the unprotected subplots (inside the yellow rectangle). The 
(2005) found that warmer winters resulted in earlier leaf senescence, but their research was conducted across locations, so warmer winters were followed by warmer spring temperatures. In our experiment, all plots were in the same field, so air temperature would not be expected to differ between treatments after winter low tunnels were removed.

Potential yields. To evaluate the production potential of saffron crocus under Rhode Island climatic conditions, we calculated the mean yield across all treatments in our trial for each year. The mean yield of dry saffron across all treatments in 2018 was $\mathbf{1 2 . 9 5}$ $\mathrm{kg} \cdot \mathrm{ha}^{-1}$. In 2019 , it was $10.4 \mathrm{~kg} \cdot \mathrm{ha}^{-1}$; yield did not differ significantly between years. For comparison, yields in Iran average $4.7 \mathrm{~kg} \cdot \mathrm{ha}^{-1}$, with a range of $15 \mathrm{~kg} \cdot \mathrm{ha}^{-1}$ in the best fields to $3.8 \mathrm{~kg} \cdot \mathrm{ha}^{-1}$ in marginal fields. Yields in Spain average 10 to $12 \mathrm{~kg} \cdot \mathrm{ha}^{-1}$, with 6 to $10 \mathrm{~kg} \cdot \mathrm{ha}^{-1}$ for the first planting year (Molafilabi, 2006) In Greece and Italy, yields average $10 \mathrm{~kg} \cdot \mathrm{ha}^{-1}$ (Alonso Diaz-Marta et al., 2006).

\section{Conclusions}

We showed that saffron crocus could survive and produce an acceptable yield in the climate of southern New England. Our yields were similar to yields in the saffron production centers of Europe, and approached the yields from the very best fields in Iran. With a minimum price of $\$ 20 / \mathrm{g}$ for locally grown saffron, an annual yield of $10 \mathrm{~kg} \cdot \mathrm{ha}^{-1}$ will result in about $\$ 81,000 /$ acre of gross revenue. Harvest labor is the primary production cost after saffron is established. A worker can harvest 8 to $16 \mathrm{~kg}$ of flowers per day, depending on skill and conditions in the field (Alonso DiazMarta et al., 2006). This translates to between 107 and $212 \mathrm{~g}$ of dried saffron per worker per day (assuming an 8 -h workday). If the hourly wage is $\$ 11$, harvest labor would cost \$3341 for 1 acre of saffron crocus. Production costs other than for harvest are similar to those for garlic (Allium sativum) production.

Winter protection was both unnecessary and counterproductive for saffron crocus in southern New England. Increasing planting density greater than $120 \mathrm{corms} / \mathrm{m}^{2}$ did not increase yields in our fertile soil after the planting year. The optimal frequency of digging and replanting has not been identified for saffron crocus production in the northeastern United States. If plants become too crowded after just l year, Rhode Island's best density may be less than the density proposed for short-duration plantings by researchers in Iran, Italy, or Spain. Corms are a major expense when establishing a new saffron crocus planting, so further research should be conducted to identify the planting density, which balances yield with costs for both corms and land.

\section{Literature cited}

Alonso, G.L., A. Zalacain, and M. Carmona. 2012. Saffron, p. 469-498. In: K.V. Peters (ed.). Handbook of herbs and spices. Vol. 1. Woodhead Publishing, Oxford, UK

Alonso Diaz-Marta, G.L., A. Arghittu, K. Astraka, T. Betza, E. Camba, W. Canadas Sanchez, M. Carmona Delgado, M.T. Cilloco, J. Corona, M. Curreli, D. Daferera, A. De Juan Valero, Y. Fallas, G. Fenza, I. Floris, G. Ibba, M. Ibba, E. Garcia Lopez De Rodas, M.J. Garrido Garcia, V. Gkoutzios, C. Kanakis, R. Laconi, A. Leoudis, H. Lopez Corcoles, P. Lopez Fuster, G. Lusso, M. Manconi, W. Marras, G. Mulas, G. Murgia, M.V. Onnis, R. Peddis, I. Pes, R. Picornell Buendia, M.E. Pinna, A. Pirastu, A.E. Pirisi, M.G. Polissiou, S. Podda, K. Rakitzis, P. Remoundos, M.J. Romero Del Rey, T. Sajardo Lucas, A.M. Sanchez Gomez, R. Salinas Fernandez, F. Sanna, S. Sanna, B. Satta, T. Selis, P.A. Tarantilis, M. Venusti, and A. Zalacain. 2006. Saffron in Europe: Problems and strategies for improving the quality and strengthen competitiveness. SAFFRON Project, European Union INTERREG IIIC South Programme, Valencia, Spain.

Andabjadid, S.S., B. Pasban Eslam, A.R. Sadeghi Bakhtavari, and H. Mohammadi. 2015. Effects of corm size and plant density on saffron (Crocus sativus L.) yield and its components. Intl. J. Agron. Agr. Res. 6:20-26.

Begoña, R.M., S.G. Nebauer, V. García-Carpintero, J. Cañizares, E.G. Minguet, M. de los Mozos, and R.V. Molina. 2021. Flower induction and development in saffron: Timing and hormone signaling pathways. Ind. Crops Prod. 164:113370, doi: 10.1016/j. indcrop.2021.113370.

Cardone, L., D. Castronuovo, M. Perniola, N. Cicco, and V. Candido. 2020. Saffron (Crocus satious L.), the king of spices: An overview. Scientia Hort. 272:109560, doi: 10.1016/j.scienta.2020.109560.
Christodoulou, E., N.P. Kadoglou, N. Kostomitsopoulos, and G. Valsami. 2015. Saffron: A natural product with potential pharmaceutical applications. J. Pharm. Pharmacol. 67:1634-1649, doi: 10.1111/ jphp. 12456.

Dar, M.H., R. Groach, S.M. Razvi, and N. Singh. 2017. Saffron crop (golden crop) in modern sustainable agricultural systems. Intl. J. Res. Appl. Sci. Eng. Technol. 5:247-259, doi: 10.22214/ijraset.2017. 11037 .

de Juan, J.A., L. Corcoles, R. Munoz, and R. Picornell. 2009. Yield and yield components of saffron under different cropping systems. Ind. Crops Prod. 30:212-219, doi: 10.1016/j.indcrop.2009.03.011.

Elhajj, A.K., M. Sally, S. Oleik, V. Telj, N. Taha, H. Chehabeldine, and T. Tachach. 2019. The yield of saffron (Crocus sativus) under different corm densities. J. Agr. Sci. 11:183-187, doi: 10.5539/ jas.vlln8pl83.

Fallahi, H.R. and S. Mahmoodi. 2018. Impact of water availability and fertilization management on saffron (Crocus sativus L.) biomass allocation. J. Hort. Postharvest Res. 1:133-148, doi: 10.22077/jhpr. 2018.1487.1017.

Food and Agriculture Organization of the United Nations. 2018. Qanat-based saffron farming system in Gonabad, Iran. 10 Feb. 2021. <http://www.fao.org/giahs/giahs aroundtheworld/designated-sites/asia-andthe-pacific/qanat-based-saffron-farmingsystem-in-gonabad/detailed-information/ en $/>$.

Ghalehgolabbehbahnai, A., B.L. Parker, and M. Skinner. 2017. Growing saffron in Vermont high tunnels. 17 Mar. 2021. <https://www.uvm.edu/\%7Esaffron/Work shops/Saffron\%20Workshop\%202017/ VermontSaffron-ArashG.pdf $>$.

Gohari, A.R., S. Saeidnia, and M.K. Mahmoodabadi. 2013. An overview on saffron, phytochemicals, and medicinal properties. Pharmacogn. Rev. 7(13):61-66, doi: 10.4103/0973-7847.112850.

Golmohammadi, F. 2014. Saffron and its farming, economic importance, export, medicinal characteristics, and various uses in South Khorasan Province-East of Iran. Intl. J. Farming Allied Sci. 3:566-596.

Grand View Research. 2020. Saffron market size, share and trends analysis report and segment forecasts, 2020-2027. Rep. GVR-1-68038-471-0. 19 Apr. 2021. <https://www.grandviewresearch.com/ industry-analysis/saffron-market $>$.

Gresta, F., G. Avola, G.M. Lombardo, L. Siracusa, and G. Ruberto. 2009. Analysis of flowering, stigmas yield, and qualitative traits of saffron (Crocus sativus L.) as 
affected by environmental conditions. Scientia Hort. 119:320-324, doi: 10.1016/ j.scienta.2008.08.008.

Gresta, F., G.M. Lombardo, L. Siracusa, and G. Ruberto. 2008. Saffron, an alternative crop for sustainable agricultural systems: A review. Agron. Sustain. Dev. 28:95-112, doi: 10.1051/agro:2007030.

Heinitsh, C.A. 1867. Note on the culture of saffron in Pennsylvania. Amer. J. Pharm. 39:38-39.

Kafi, M. 2006. Saffron ecophysiology, p. 30-44. In: M. Kafi, A. Koocheki, and M.H. Rashed-Mohasel (eds.). Saffron (Crocus sativus): Production and processing. 1st ed. Science Publishers, Enfield, NH.

Khademi, K., A. Sepahvand, A. Mohammadian, and S. Ahmadi. 2014. Study of saffron in dry land farming and irrigated conditions in a period of six years in the city of Khoramabad Province. J. Saffron Res. 1(2):110-119. (in Persian).

Koocheki, A., P. Rezvani-Moghaddam, M. Aghhavani-Shajari, and H.R. Fallahi. 2019. Corm weight or number per unit of land: Which one is more effective when planting corms, based on the age of the field from which corms were selected? Ind. Crops Prod. 131:78-84, doi: 10.1016/j.indcrop. 2019.01.026.

Koocheki, A. and S.M. Seyyedi. 2020. Saffron "seed", the corm, p. 93-118. In: A. Koocheki and M. Khajeh-Hosseini (eds.). Saffron: Science, technology, and health. lst ed. Woodhead Publishing, Sawston, UK.

Marcuss, M. and R. Borgos. 2004. Who are New England's immigrants? 13 June 2021. <https://www.bostonfed.org/-/media/ Documents/cb/PDF/Immigrants.pdf $>$.

Mohammadi, H. and M. Reed. 2020. Saffron marketing: Challenges and opportunities, p. 357-365. In: A. Koocheki, and M. Khajeh-Hosseini (eds.). Saffron: Science, technology, and health. lst ed. Woodhead Publishing, Sawston, UK.

Molafilabi, A. 2004. An experimental finding of production and ecophysiological aspect of saffron (Crocus sativus L.). Acta Hort. 650:195-200, doi: 10.17660/ ActaHortic.2004.650.20

Molafilabi, A. 2006. Saffron production technology, p. 59-78. In: M. Kafi, A. Koocheki, and M.H. Rashed-Mohasel (eds.). Saffron (Crocus sativus): Production and processing. 1st ed. Science Publishing, Enfield, NH.

Molina, R.V., M. Valero, Y. Navarro, J.L. Guardiola, and A. Garcia-Luis. 2005. Temperature effects on flower formation in saffron (Crocus sativus L.). Scientia Hort. 103:361-379, doi: 10.1016/j.scienta. 2004.06.005.

Mzabri, I., M. Addi, and A. Berrichi. 2019. Traditional and modern uses of saffron (Crocus sativus). Cosmetics 6:63, doi: 10.3390/cosmetics6040063.

Rahimi, H., M. Shokrpour, L. Tabrizi Raeini, and E. Esfandiari. 2017. A study on the effects of environmental factors on vegetative characteristics and corm yield of saffron (Crocus sativus). Iran. J. Hort. Sci. 48:45-52. (in Persian).

Renau-Morata, B., S.G. Nebauer, M. Sanchez, and R.V. Molina. 2012. Effect of corm size, water stress, and cultivation conditions on photosynthesis and biomass partitioning during the vegetative growth of saffron (Crocus sativus L.). Ind. Crops Prod. 39:40-46, doi: 10.1016/j.indcrop. 2012.02.009.

Rezvani-Moghaddam, P. 2020. Saffron ecophysiology, p. 119-137. In: A.
Koocheki and M. Khajeh-Hosseini (eds.). Saffron: Science, technology, and health. lst ed. Woodhead Publishing, Sawston, UK.

Schmidt, T., T. Heitkam, S. Liedtke, V. Schubert, and G. Menzel. 2019. Adding color to a century-old enigma: Multicolor chromosome identification unravels the autotriploid nature of saffron (Crocus sativus) as a hybrid of wild Crocus cartwrightianus cytotypes. New Phytol. 222: 1965-1980, doi: 10.1111/nph.15715.

Sideman, R.G., A. Brown, C.A. Martin, R. Hazzard, and A. Cavanagh. 2012. Temperature moderating effects of low tunnels over winter in cool climates. HortScience 47:S404-S405. (Abstr.).

Simon, J.E., A.F. Chadwick, and L.E. Craker. 1984. Herbs: An indexed bibliography. 1971-1980: The scientific literature on selected herbs, and aromatic and medicinal plants of the temperate zone. Archon Books, Hamden, CT.

Temperini, O., R. Rea, A. Temperini, G. Colla, and Y. Rouphael. 2009. Evaluation of saffron (Crocus sativus L.) production in Italy: Effects of the age of saffron fields and plant density. J. Food. Agr. Environ. 7:19-23, doi: 10.1234/4.2009.1386.

United Nations. 2021. Annual international trade statistics by country. 8 Feb. 2021. <https://trendeconomy.com/>.

United States Department of Agriculture. 2019. 2017 Census of agriculture. U.S. Department of Agriculture, National Agricultural Statistics Service, Washington, DC.

Yarami, N. and A. Sepaskhah. 2015. Saffron response to irrigation water salinity, cow manure, and planting method. Agr. Water Mgt. 150:57-66, doi: 10.1016/j. agwat.2014.12.004. 